\title{
The effect of ethepon treatment on the formation of flower in melon (Cucumis melo L.)
}

\author{
Budi Setiadi Daryono*, Eko Prasetya, Sumarlina, Dian Sartika, and \\ Aprilia Sufi Subiastuti
}

Laboratory of Genetics and Breeding, Faculty of Biology, Universitas Gadjah Mada Teknika Selatan Street, Sekip Utara, Yogyakarta, Indonesia 55281

*e-mail: bs_daryono@mail.ugm.ac.id

\begin{abstract}
Melon is a potential horticultural crop which the production is increased significantly each year in Indonesia. However, a melon plant that has been widely developed in Indonesia faced a problem due to the high tropical temperature that affected the fall of flower causing failure in fruit production. In addition, the variation of sex expression in melon flower is important for genetic analysis and breeding programs. Ethepon is one of plant chemical growth regulator that is known to change the sex expression of the plant by increasing the number of female flower in monoecious plant especially Cucurbitaceae. This research aimed to analyze the effect of ethepon treatment on the sex determination of melon flower. This study was conducted by 3 stages treatment of ethepon during March - July 2014, namely when 2, 5, and 7 weeks after planting. Split-plot design has been used with the main plots were arranged in a completely randomized design by cultivating different melon cultivars i.e: Melodi Gama 1, Melodi Gama 3, Bartek, and PI 371795. The data were analyzed by F-test and Duncan Multiple Range Test (DMRT) with significance level at $5 \%$ using software SAS 9.3. The result showed that ethepon treatment affected the formation of melon flower by increasing the number of female or hermaphrodite flower and decreasing the number of male flowers, especially in the concentration of $75 \mathrm{ppm}$ and $100 \mathrm{ppm}$ but with different responses by different cultivar.
\end{abstract}

\section{Keywords}

ethepon, flower formation, sex expression, melon, plant breeding

Citation: Daryono, B. S., Prasetya, E., Sumarlina, Sartika D., \& Subiastuti, A. S. (2018). The effect of ethepon treatment on the formation of flower in melon (Cucumis melo L.). In T. R. Nuringtyas, A. C. Sukartiko, \& A. Isnansetyo (Eds.), UGM Digital Press Life Sciences: Vol. 1. Proceeding of the 2nd International Conference on Tropical Agriculture, (pp. 7-13).

Published: October, 2018

\section{Introduction}

Melon (Cucumis melo L.) is one of the favorite fruits in Indonesia due to the sweet taste, freshness, and good performance. Based on the data of Direktorat Jendral Hortikultura (2004), the consumption of melon fruit is assumed to increase as the increasing of society with a range of 1.34$1.50 \mathrm{~kg} / \mathrm{capita} /$ year. Besides, the production of melon has increased each year since 2010 . Therefore, melon is a potential horticultural product to be developed as a superior fruit production through plant breeding [1]. However, cultivating melon in the tropical area faced the problem related to the high temperature which can cause the fall of flowers and failure of fruit formation. Based on the result of a research 
[2], the yield depends on the number of female flowers produced by the plant. Therefore, the application of plant growth regulator was expected to stimulate the flower formation in melon. Hence, the fruit set can be formed in high yield.

One of the plant growth regulators is ethepon. Ethrel is ethylene realizing agent containing active substance, viz.: ethepon [3]. The treatment of 1-Naphthaleneacetic acid (NAA) 100 ppm or ethepon 40 PGR $360 \mathrm{ppm}$ increased the ratio of female flower in cucumber [4]. The treatment of ethepon was expected to increase the female flower in melon. It is related to the variation of flower sex in melon which can be an important information source for genetic analysis and plant breeding program [5]. Some cultivars of melon have female and male flowers, but some others have hermaphrodite flower. The sex determination in melon is affected by a genetic factor, the plant hormone production, and environmental condition. The production of ethylene has a correlation to flower formation in melon, especially the female flower [6]. Ethylene in plant is produced through a biosynthesis pathway including a conversion of S-adenosyl methionine (SAM) becomes 1-aminocyclopropane-1-carboxylic acid (ACC) by the S-adenosyl-L-methionine methylthioadenosine-liase (ACS) [7]. This ACS in plant is encoded by andromonoecious gene which can be affected by ethepon. Therefore, this research was conducted to understand the effect of ethepon treatment on the formation of flower in melon. The clear and brief information obtained from this research can be an alternative to increase the yield of melon fruit in Indonesia. Hence, the production of melon fruit in Indonesia can meet people's demand.

\section{Methods}

The research was conducted in March - July 2014 in Pusat Inovasi Agro Teknologi (PIAT, formerly KP4) for cultivation and the laboratory of genetics and breeding, Faculty of Biology, Universitas Gadjah Mada for preparation of ethepon treatment. The cultivation was designed using Split Plot Design in combination with Completely Randomized Design. The type of melon cultivars was placed in the main plot and the concentration of ethepon as the subplot. The type of melon comprised cultivar of Melodi Gama 1 (MG1), MG3, Bartek, and PI 371795. The concentration of ethepon covered 4 levels: control (0 ppm of ethepon), 50 ppm, 75 ppm, and 100 ppm. The ethepon treatment was given in 3 stages i.e. 2 weeks, 5 weeks, and 7 weeks after panting. The observation was conducted from 2 weeks after planting (time for the first flower produced) until the number of flowers had not increased more. The data collected were consists of the time of female/hermaphrodite flower appearance, total number of each sex of flower (male, female, and hermaphrodite), and ratio of male: female: hermaphrodite flower. The data were then analyzed using SAS 9.3 software by applying Duncan Multiple Rate Test (DMRT) at a rate of $5 \%$ confidence level to confirm the significance of each treatment on each cultivar of melon.

\section{Results and Discussions}

The growth of melon population in this research was good enough during the cultivation. However, the pests and diseases damaged around $36.25 \%$ of population. The temperature of greenhouse was varies during the research, which is depend on the sunlight radiation. The highest temperature of sunny day along the research was $38{ }^{\circ} \mathrm{C}$, while the highest temperature of rainy or cloudy day was $27{ }^{\circ} \mathrm{C}$. The temperature was assumed to affect the flower formation in melon, especially on flowering mechanism of melon. Therefore, the use of ethepon was expected to be an alternative to solve this problem through this research. The effect of ethepon on the flower formation in melon is shown in Table 1. 
Table 1 The effect of ethepon on the number of flower formation in melon

\begin{tabular}{|c|c|c|c|}
\hline Ethepon Treatment & Male Flower & $\begin{array}{l}\text { Female/hermaphr } \\
\text { odite flower }\end{array}$ & Flower Ratio \\
\hline \multicolumn{4}{|c|}{ Melodi Gama 1} \\
\hline Kontrol & $59.60 \mathbf{a}$ & $4.800 \mathrm{~b}$ & $0.08022 \mathbf{b}$ \\
\hline 50 ppm & $25.60 \mathrm{~b}$ & $5.400 \mathrm{~b}$ & $0.25674 \mathbf{a b}$ \\
\hline 75 ppm & $57.40 \mathbf{a}$ & $7.000 \mathbf{b}$ & $0.12807 \mathbf{a b}$ \\
\hline $100 \mathrm{ppm}$ & $41.40 \mathbf{a b}$ & $10.80 \mathrm{a}$ & 0.30793 a \\
\hline \multicolumn{4}{|c|}{ Melodi Gama 3} \\
\hline Control & $43.60 \mathbf{a}$ & $4.200 \mathrm{~b}$ & $0.09434 \mathbf{a}$ \\
\hline 50 ppm & $52.00 \mathbf{a}$ & $6.400 \mathbf{a b}$ & $0.15462 \mathbf{a}$ \\
\hline 75 ppm & $57.60 \mathbf{a}$ & $7.400 \mathrm{a}$ & $0.14656 \mathbf{a}$ \\
\hline $100 \mathrm{ppm}$ & $62.00 \mathrm{a}$ & $3.800 \mathbf{b}$ & $0.06641 \mathbf{a}$ \\
\hline \multicolumn{4}{|l|}{ Bartek } \\
\hline Control & $71.60 \mathbf{a}$ & $5.200 \mathbf{c b}$ & $0.0732 \mathbf{a}$ \\
\hline 50 ppm & $35.60 \mathrm{~b}$ & $2.200 \mathrm{c}$ & $0.0625 \mathbf{a}$ \\
\hline 75 ppm & $77.40 \mathbf{a}$ & $6.400 \mathrm{~b}$ & $0.0930 \mathbf{a}$ \\
\hline 100 ppm & $44.60 \mathrm{~b}$ & $11.20 \mathrm{a}$ & $0.4787 \mathbf{a}$ \\
\hline \multicolumn{4}{|l|}{ PI 371795} \\
\hline Control & $47.40 \mathbf{a}$ & $3.200 \mathrm{c}$ & $0.08946 \mathbf{a b}$ \\
\hline 50 ppm & $76.20 \mathbf{a}$ & $7.600 \mathrm{ab}$ & $0.13382 \mathbf{a}$ \\
\hline 75 ppm & $80.80 \mathbf{a}$ & $3.800 \mathbf{b c}$ & $0.04669 \mathbf{b}$ \\
\hline 100 ppm & $83.60 \mathrm{a}$ & 8.600 a & $0.11746 \mathbf{a b}$ \\
\hline
\end{tabular}

Note: the vertical values which are followed by the same alphabet in one column show that they're not significantly different based on the Duncan Multiple Rate Test (DMRT)

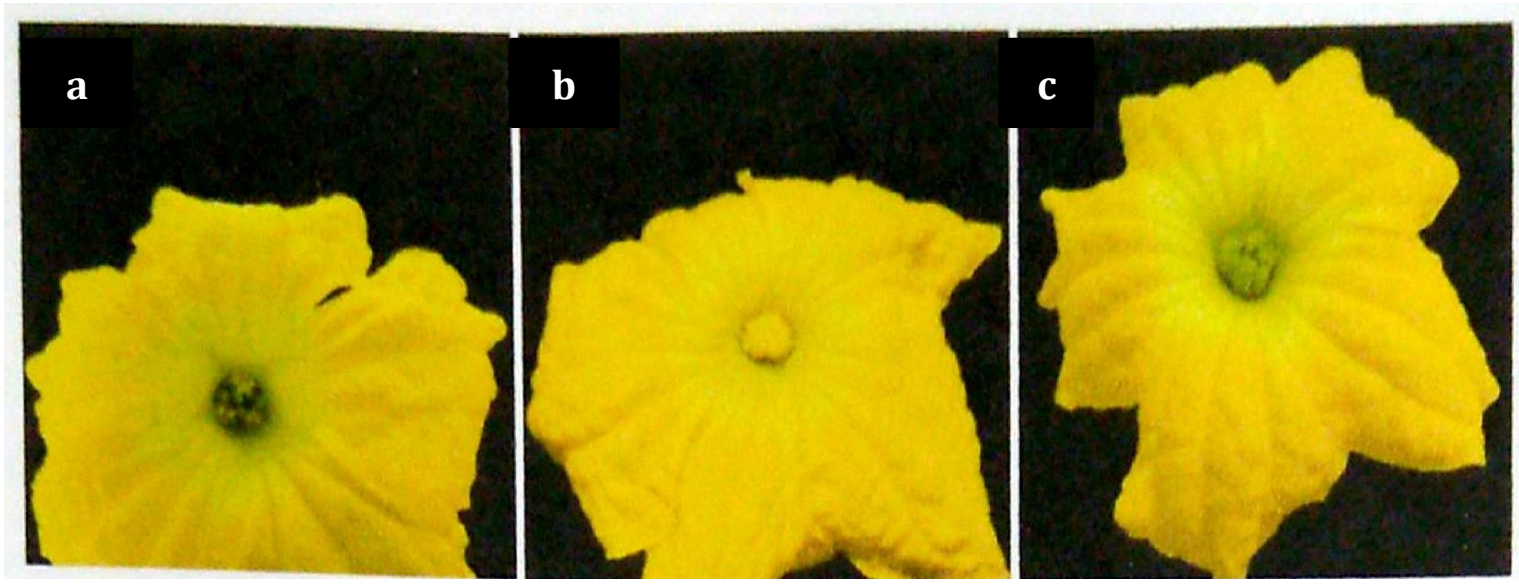

Fig. 1 The type of flowers in melon: a hermaphrodite flower, b male flower, and c female flower

The results shown in Table 1 showed that there were differences in each flower number on each cultivar but not all of the data were significantly different. All cultivars showed a reduction number of the male flower because of the ethepon treatment comparing to the control. However, two of four cultivars showed the data of male flower number and flower ratio that were not significantly different based on the statistical analysis, while the other two were significantly different. On the other hand, the effect of ethepon was also affected the female or hermaphrodite flower in melon with different response in each cultivar. The comparison of the effect is shown in Fig. 2 and Fig. 3. 


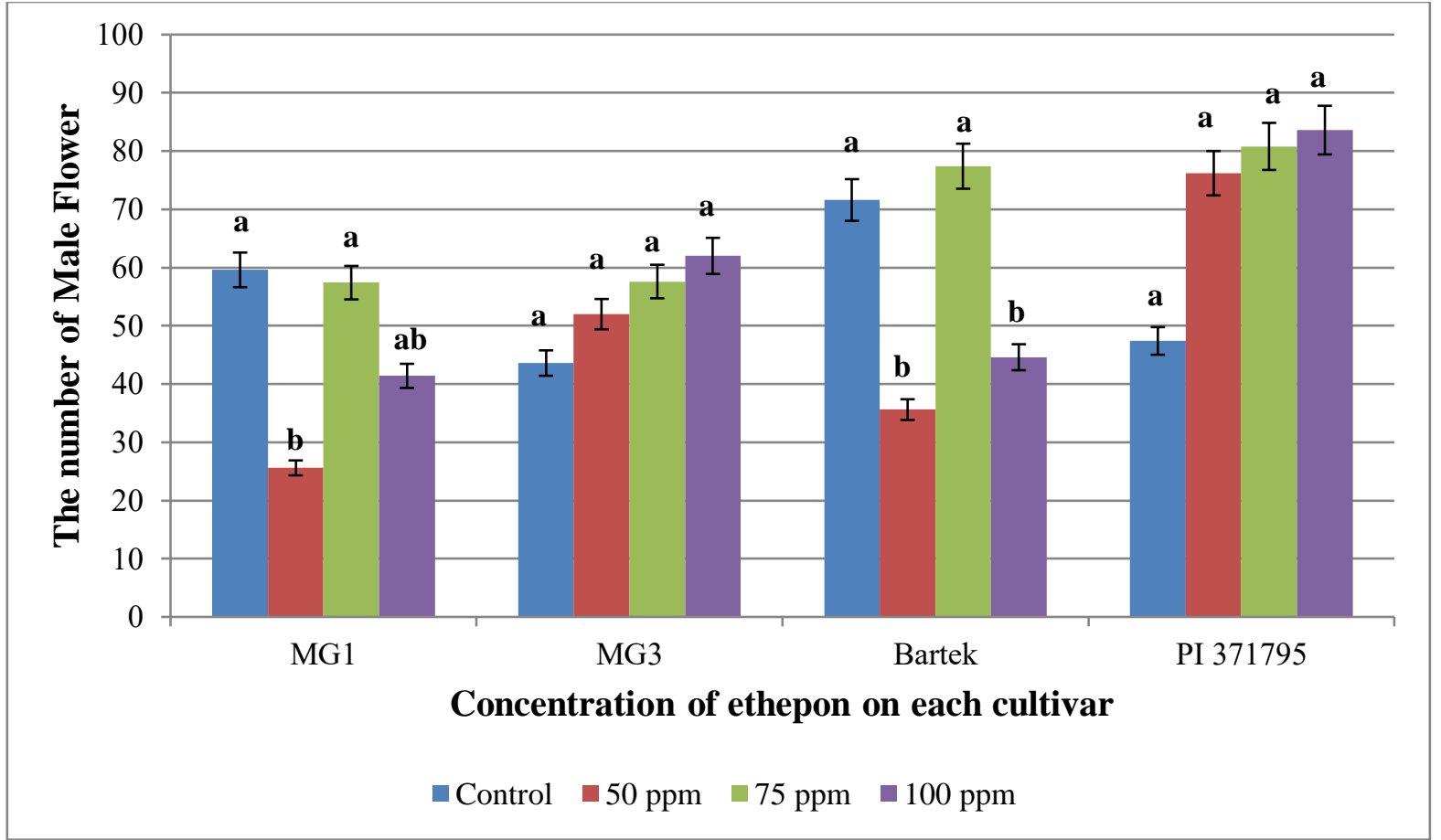

Fig. 2 Variation of the effect of ethepon treatment on the male flower formation. The bars which are followed by the same alphabet in each category (each melon cultivars) show that they are not significantly different based on the Duncan Multiple Rate Test (DMRT) at a rate of $5 \%$

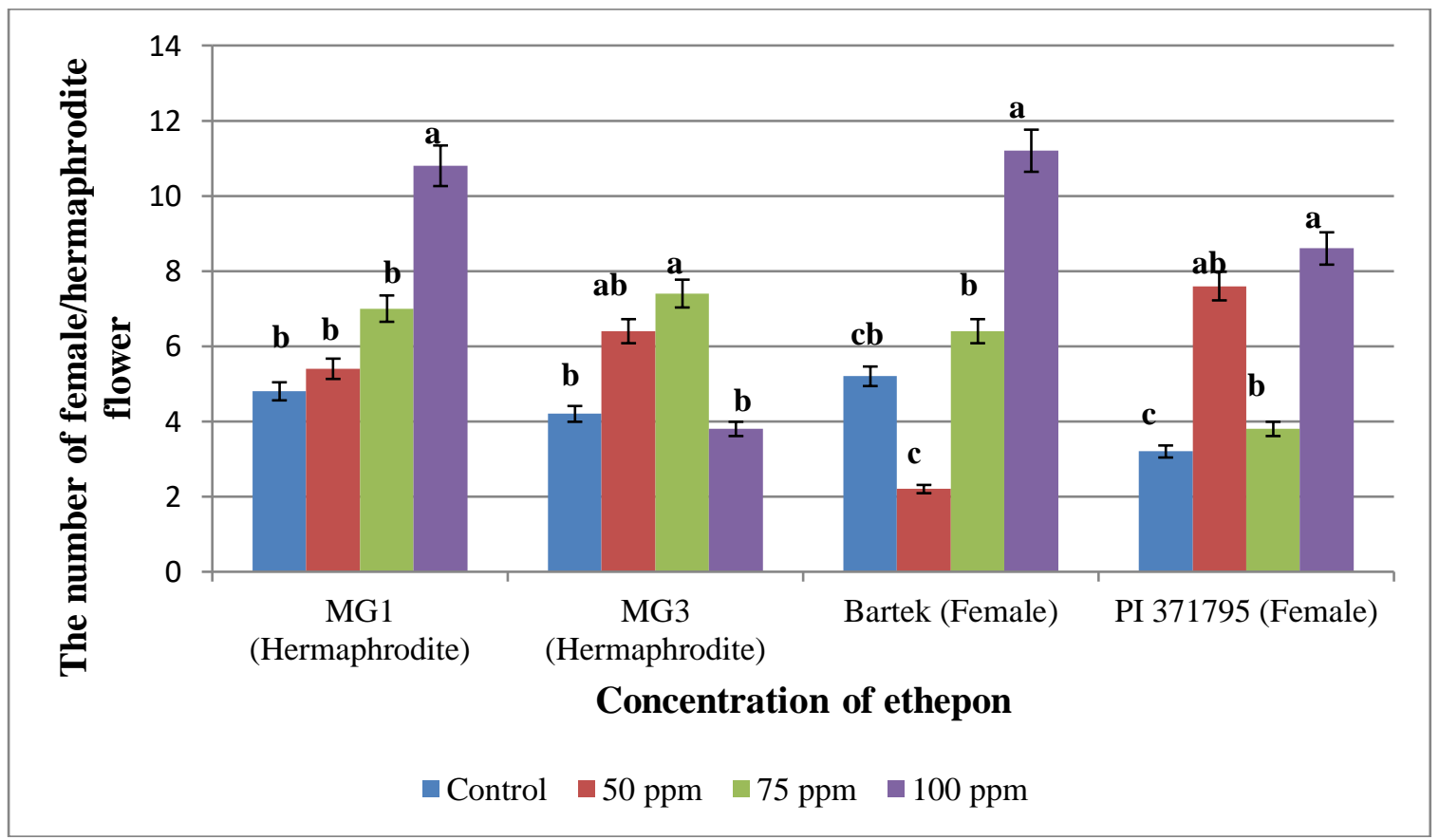

Fig. 3 Variation of the effect of ethepon treatment on the female/hermaphrodite flower formation. The bars which are followed by the same alphabet in each category (each melon cultivars) show that they are not significantly different based on the Duncan Multiple Rate Test (DMRT) at a rate of $5 \%$

The results in Fig. 2 and Fig. 3 showed that the ethepon treatment reduced the male flower formation only in Bartek, but not in MG1. The male flower formation in MG3 and PI 371795 is increased as the increasing of ethepon's concentration linearly but not significantly different by statistical measurement. The results also showed that the ethepon treatment with concentration of $100 \mathrm{ppm}$ influenced the female flower formation significantly in melon MG1, Bartek, and PI 371795, while the 75 ppm ethepon treatment influenced significantly on the female flower formation of melon MG3. Besides, the 50 ppm ethepon treatment influenced significantly on the female flower formation of melon PI 371795. It means that the 
effects of ethepon treatment were also depended on the cultivar. Each cultivar showed a different level of response to the treatment. However, it was clear that the ethepon treatment affected the flowering system in melon. This effect was known that could be at the different time on each cultivar according to the observation in three times stages i.e. 7, 14, and 21 days after treatment (DAT). The effect of ethepon treatment can be identified in plant at 15 days after treatment [8]. This research showed that the ethepon treatment in concentration of $50 \mathrm{ppm}$ affected significantly on the flowering time of the female flowers on Bartek and hermaphrodite flower on MG1, but not significantly affected on MG3 and PI 371795. The ethepon treatment in $50 \mathrm{ppm}$ concentration significantly affected on the hermaphrodite flower formation of MG1 in 14 and 21 days after treatment (DAT) and on the female flower formation of Bartek in 21 DAT. This time management in melon is related to the development of the plant itself. Plants have a complex regulation through the hormonal, genetic, physiological, and other kind of regulation during their lifespan. A chemical treatment affected the regulation through many ways, especially the biosynthetic pathway of the plant.

The treatment of ethylene precursor in melon reduces the development of male flower [9]. Ethepon is a part of Chemical Hybridizing Agents (CHAs) or commonly known as male gametocide, male sterillant, pollenocide, or androcide. Ethepon influences varies phase of plant growth and development. Ethepon is a plant growth regulator that can change the sex expression in Cucurbitaceae, especially increasing the number of female flower of monoecious plant [10]. Besides, this chemical substance can cause a male sterility, a condition of failure of functional pollen production in plant. The male sterility can be formed as reducing of pollen number significantly, changing of male flower including the pollen, and failure of stamen rupture in the time of releasing pollen [11]. This effect is related to the genetic regulation, especially the expression of Anromonoecious gene. Andromonoecious gene is expressed only in flower formation which has a role on the formation of 1-aminocyclopropane-1-carboxylic acid synthase (ACS) that refers to $C m A C S$ 7 gene, a gene for sex determination in melon [12]. This gene is involved in the formation of female or hermaphrodite flower by stimulating the pistil formation. A research in watermelon also showed that the the transcription level of ACS homologous is recognized as andromonoecious gene in plant growth regulator and silver nitrate treatments [13].

In contrast to the first effect mentioned before, the ethepon treatment that is more than $100 \mathrm{ppm}$ can decrease the number of female, hermaphrodite, and male flower significantly [14]. The most possible reason is related to the content of ethylene, anti-gibberellin which can stop the process of mitotic division of roots and buds.

A research in watermelon, another member of Cucurbitaceae showed that external treatments with ethepon inhibits the transition from male to female flowering and reduces the number of pistillate flowers per plant, which runs contrary to findings in other Cucurbit species [15]. Other research showed that the ethepon treatments reduced the percentage of female flowers and delayed the occurrence of the first female flower [13]. The two researches showed different responses in watermelon flowering mechanism affected by ethepon treatment compared to other member Cucurbit species. A research in Litchi chinensis Sonn also showed that the ethepon treatment significantly increased fruit abscission and ethylene production of fruitlet by triggering abscission signaling and changing the polar transport of auxin [16] However, the use of $150 \mathrm{mg} / \mathrm{L}$ was the optimal concentration for improving the proportion of bisexual flower in pomegranate which was consistent with the transcriptomics results [17]. These researches mean that the effect of ethepon treatment was species specific. Therefore, $t$ is important to know the effect of the ethepon first before applying on every cultivated plant.

The male sterility made the cross-breeding is happened. The use of CHAs made the combination of each parental was possible to produce a hybrid, but the phytotoxic effect must be at low level to keep the fruit quality in good performance [18]. In many cases of plant breeding, male sterility is needed to control the hybrid plant production by preventing the self-pollination [19]. Producing a hybrid melon is commonly conducted by cross-pollination in gynoecious plant as the female parental, hand-emasculation in andromonoecious and monoecious plant, and ethepon treatment to reduce the development of male flower but stimulate the female flower formation. The ethepon treatment helps to reduce hand-emasculation in cross-pollination of Cucurbitaceae [20]. It has been reported that the ethepon have the gametocide effect on the pollen of rice [21]. Therefore, many seed companies have used ethepon to produce the hybrid seed. Based on the research that have been conducted, the ethepon treatment showed a variation effects on each melon cultivar, concentration of ethepon, time of treatment, and the duration of treatment. On the other hand, the development of flower formation can increase the possibility of melon fruits in good performance. The ethepon treatment in 100 ppm concentration on the hermaphrodite flower of melon "Shirayuki" could produce melon fruits with better quality, faster harvesting, and longer diameter (bigger size) than the plants without the ethepon treatment [22]. In contrast, a high concentration of ethepon treatment may also 
give negative effect on the fruit quality as the research conducted before which showed decreasing of fruit weight) caused by the $200 \mathrm{ppm}$ of ethepon [8] and the $300 \mathrm{ppm}$ of ethepon treatment [23]. This information could be some specific consideration in hybrid melon production. Hence, the sustainable production of melon fruit in Indonesia can be achieved not only in number, but also the quality.

\section{Conclusions}

The ethepon treatment affected the formation of melon flower by increasing the number of female or hermaphrodite flower and decreasing the number of male flowers, especially in concentration of $75 \mathrm{ppm}$ and $100 \mathrm{ppm}$, although some of data were not significantly different between control and treatment based on the statistical analysis. However, it was clearly proven that the ethepon treatment reduced the number of male flower and increased the number of female or hermaphrodite flower, but with different level of responses on each cultivar of melon. Hence, the ethepon treatment can be an alternative to produce a sustainable melon fruit production.

Acknowledgments The authors would like to thank to Hibah Riset MP3EI (Masterplan, Perluasan dan Percepatan Pembangunan Ekonomi Indonesia) LPPT-UGM/1259/LIT/2014 for supporting this research and Hibah Penelitian Unggulan Strategis Nasional (PUSNAS) 1072/UN1-P.III/DIT-LIT/LT/2017 for making the development of this research possible by supporting the next stage of this research. The authors would also like to thank to PIAT UGM for permitting the use of greenhouses during the research. In addition, special thanks to Dr. rer. nat. Ari Indrianto, S.U. and Dr. Purnomo M.S. for the guidance in this research and Gama Melon team for the good works together in every step of this research.

\section{References}

1. Daryono, B. S., Maryanto, S. D.: Keanekaragaman dan Potensi Sumber Daya Genetik Melon [Diversity and Potential of Melon Genetic Resources]. Universitas Gadjah Mada Press, Yogyakarta (2017). [In Bahasa Indonesia].

2. Prohens, J., Nuez, F.: Vegetables I: Asteraceae, brassicaceae, chenopodiaceae, and cucurbitaceae. Springer, New York (2008).

3. Abeles, F. B.: Ethylene in plant biology. Academic Press. New York (1973).

4. Sumiati, S. \& Sumarni, N.: Peran Zat pengatur tumbuh terhadap nisbah bunga betina \& jantan serta produksi tanaman mentimun. [Role of growth regulator substances on female \& male flower ratio and cucumber plant production.]. J. Hort. 6(1): 17-22 (1996). [In Bahasa Indonesia]. [Unpublished Online]

5. Ouzounidou, G., Papadopoulou, P., Giannakoula, A., Ilias, I.: Plant growth regulators treatments modulate growth, physiology and quality characteristics of Cucumis melo L. plants. Pakistan Journal of Botany 40(3), 1185-1193 (2008).

6. Takashi, H., Jaffe, M.J.: Further studies of auxin and ACC induced feminization in the cucumber plant using ethylene inhibitors. Phyton 44, 81-86 (1984).

7. Yang, S.F., Hoffman, N. E.: Ethylene biosynthesis and its regulation in higherplants. Annual Review of Plant Physiology 35, 155-189 (1984).

8. Arabsalmani, K., Jalali, A.H., Hasanpour, J.: Control of sex expression in Cantaloupe (Cucumis melo L.) by ethephon application at different growth stages. International Journal of AgriScience 2(7), 605-612 (2012).

9. Sasmito, M. A.: Pengaruh Perlakuan ethrel \& NAA terhadap pembentukan bunga \& nisbah kelamin tanaman mentimun (Cucumis Sativus). [The effect of ethrel \& NAA on the formation of flowers \& sex ratio of cucumber plants (Cucumis sativus)]. Departemen Biologi, Fakultas Matematika \& Ilmu 
Pengatahuan Alam, Institut Pertanian Bogor, Bogor. (2005). [In Bahasa Indonesia]. [Unpublished Online]

10. Robinson, R.W., Decker-Walters, D.W.: Cucurbits: Crop production science in horticulture. CAB International, United Kingdom (1997).

11.Wei, F., Hu, J., Zhang, X., Cheng, L., Du, J., Si, Y., Cao, G., Tian, B.: Male sterility induced by chemical SQ-1, as an effective male specific gametocide in maize (Zea mays), Maydica 57, 224-248 (2012).

12. Boualem, A., Fergany, M., Fernandez, R., Troadec, C., Martin, A., Morin, H., Sari, M.A., et al.: A conserved mutation in an ethylene biosynthesis enzyme leads to andromonoecy in melons. Science 321(5890), 836-838 (2008).

13.Zhang, J., Shi, J., Ji, G., Zhang, H., Gong, G., Guo, S., Ren, Y., et al.: Modulation of sex expression in four forms of watermelon by gibberellin, ethepon and silver nitrate. Horticultural Plant Journal 3(3), 91-100 (2017).

14. Kenigsbuch, D., Cohen, Y.: The inheritance of gynoecy in muskmelon. Genome 33(3), 317-320 (1990).

15. Manzano, S., Martinez, C., Garcia, J.M., Megias, Z., Jamilena, M.: Involvement of ethylene in sex expression and female flower development in watermelon (Citrullus lanatus). Plant Physiology and Biochemistry 85, 96-104 (2014).

16. Li, C., Wang, Y., Ying, P., Ma, W., Li, J.: Genome-wide digital transcript analysis of putative fruitlet abscission related genes regulated by ethepon in litchi. Frontiers in Plant Science (6), 1-16 (2015).

17. Chen, L., Zhang, J., Li, H., Niu, J., Xue, H., Liu, B., Wang, Q., et al.: Transcriptomic analysis reveals candidate genes for female sterility in pomegranate flowers. Frontiers in Plant Science 8, 1430 (2017). doi://doi.org/10.3389/fpls.2017.01430

18. Cross, J.W., Ladyman, J.A.R.: Chemical agents that inhibit pollen development: Tools for research. Sexual Plant Reproduction 4(4), 235-243 (1991).

19. Chakraborty, K., Devakumar, C.: Evaluation of chemical compounds for induction of male sterility in wheat (Triticum aestivum L.). Euphytica 147(3), 329-335 (2006).

20. Papadopoulou, E., Little, H.A., Hammar, S.A. Grumet, R.: Effect of modified endogenous ethylene production on sex expression, bisexual flower development and fruit production in melon (Cucumis melo L.). Sexual Plant Reproduction 18(3), 131-142 (2005).

21.Virmani, S.S.: Hybrid rice technology new development and future prospects. pp. 7-20. International Rice Research Institute, Philippines (1994).

22. Yasufumi, F., Yasuyo, N., Kazuhiko, S.: Effect of ethephon on sex expression in melon 'Shirayuki'hermahrodite flower expression on main stem nodes. Journal of Japanese Society Agricultural Technology Management 10(2), 89-97 (2003).

23. Radwan, A.A. (1988). Effect of Ethephon on growth, flowering and sex expression of monoceous cucumber plants. Cairo Univ. (Egypt). Faculty of Agriculture. 13: 378-884 (2003). 